\title{
Climate Analysis to Predict Potential Spread and Seasonality for Global (COVID-19) in Iraqi Kurdistan Region
}

\author{
Hemin Nasraldin M. Amin \\ Geography department \\ College of Education \\ University of Garmian \\ Kalar, Sulaimani, Iraq \\ hemin.nasraldin@garmian.edu.krd
}

\author{
Hero Nasraldin M. Amin \\ Geography department \\ College of Education \\ University of Garmian \\ Kalar, Sulaimani, Iraq \\ hero.nasraldin@garmian.edu.krd
}

\begin{tabular}{l} 
Article Info \\
\hline Special Issue on \\
Coronavirus (COVID-19) \\
DOI: \\
10.24017/covid.9 \\
Article history: \\
Received: 09 May 2020 \\
Accepted: 20 May 2020 \\
\hline
\end{tabular}

Keywords:

Climate, COVID-19,

Kurdistan Region,

Pandemic,

Seasonality

\begin{abstract}
The present study is about the relationship of the climate to the possibility of turning (COVID-19) into a seasonal epidemic in Iraqi Kurdistan region. The study area is located in the northern Iraq, within subtropical zone in northern hemisphere, it lies between two latitudes $\left(32^{\circ} 38^{\prime}-37^{\circ} 22^{\prime}\right) \mathrm{N}$ and longitudes $\left(41^{\circ} 18^{\prime}-46^{\circ} 21^{\prime}\right) \mathrm{E}$. It surrounded by Turkey from north, the Islamic Republic of Iran from east, Syria from northwest and with other parts of Iraq from south and west. To achieve the aim of this study, these topics were analyzed (climatic analysis to spatial variation of (COVID-19) outbreak through the world, climatic characteristics of the study area, and seasonal and spatial danger degree analysis to (COVID19) in the study area). The evidences indicated that cold and dry conditions may facilitate the spread of the virus. According to the study area the lower the temperature is the greater relative humidity will be and vice versa. Therefore, the study assumed that seasonal differences of temperature and humidity in different regions of the study area might contribute to the balanced risk of infection with the virus.
\end{abstract}

Copyright (ㅇ 2020 Kurdistan Journal of Applied Research. All rights reserved.

\section{INTRODUCTION}

Climate as a major component of the natural environment can affect all aspects of life, as well as human health. So, the transmission of viruses can be affected by a number of factors, such as climate conditions (especially temperature and humidity), population density and medical care quality. Therefore, through understanding the relationship between climate and the transmission of (COVID-19) can predict the intensity and ending time of this disease. However, heretofore, it is still unknown whether such a relationship exists or not [1]. There 
are lots of conventional wisdom out there that common colds and influenza are seasonal issues and tend to subside during the warm season so this will too. Also, some studies found that the disease first distributed along the $(30-50)^{\circ}$ North at consistently similar weather patterns including of temperature and humidity [2]. Therefore, it is assumed that different temperature degree and humidity ratio in seasons might also contributed to the unbalanced of infections.

In early December 2019, Coronavirus Disease 2019 (COVID-19), caused by (SARS-CoV-2), broke out in Wuhan, China. This kind of coronavirus had been confirmed to have human-tohuman transmissibility that spread across the world as well as Iraqi Kurdistan region. The question is: if the disease will turn into a seasonal disease such as flu and colds, how it will be in the study area. Here came the idea of this research, which came as these questions: (To what extent the seasonal and spatial variations of climate condition are in the study area? if (COVID-19) becomes a seasonal respiratory, can its spread be expected according to different seasons and places in the study area?)

As a preliminary answer, it can be assumed that obvious variations are in the values of climatic elements in the four seasons and different areas in the study area. And If (COVID-19) has become seasonal epidemic, then there may be seasonal and spatial variations of its outbreak in the study area.

The research came to study the seasonal and spatial variation of the climate condition of the study area, in case the virus become a seasonal epidemic, in order to take the necessary measures for the safety of citizens during the dangerous period.

\section{METHODS AND MATERIALS}

\subsection{Method}

In order to carry out the present study, the required data were collected from (10) climatic stations widely distributed over Iraqi Kurdistan region (Figure 1). Analysis and interpretative have been done to indicate the climate condition. The geographic and climatic maps output of the study area were generated by (Arc Map GIS 10.5) software. These maps evaluated for studying the spatial and seasonal variations of climate condition.

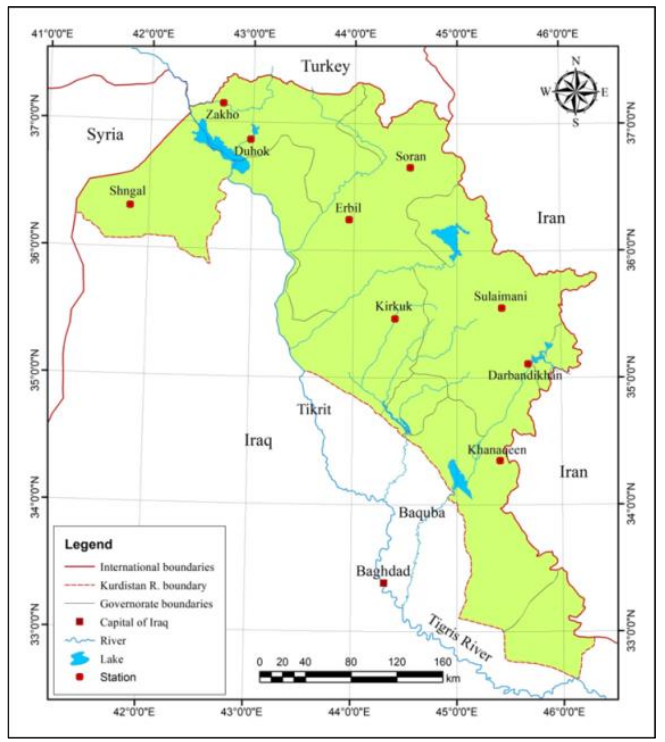

Figure 1: Geographic map of the study area with locations of (10) meteorological stations (Arc Map GIS 10.5) 


\subsection{Study Area}

The study area is located in the northern Iraq, within subtropical zone in northern hemisphere, it lies between two latitudes $\left(32^{\circ} 38^{\prime}-37^{\circ} 22^{\prime}\right) \mathrm{N}$ and longitudes $\left(41^{\circ} 18^{\prime}-46^{\circ} 21^{\prime}\right)$ E (Figure 2). It surrounded by Turkey from north, the Islamic Republic of Iran from east, Syria from northwest and with other parts of Iraq from south and west.

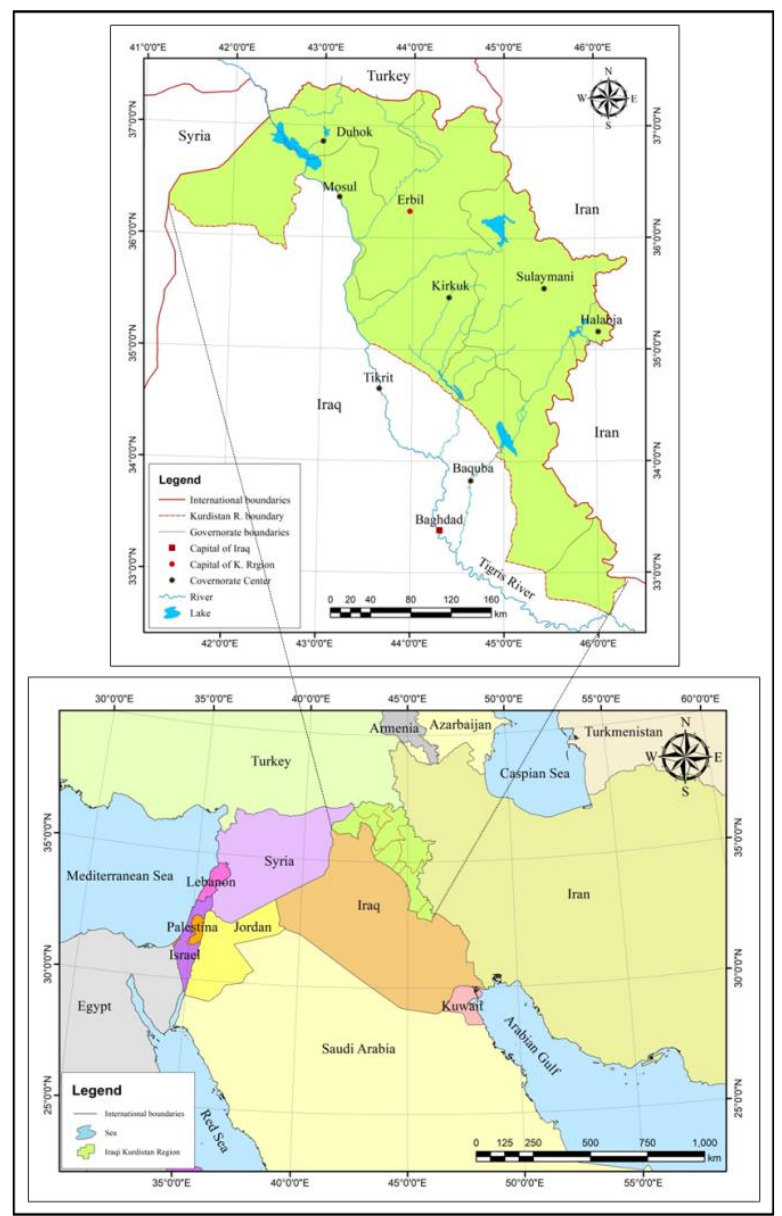

Figure 2: Astronomical and geographical location of the study area (Arc Map GIS 10.5)

\subsection{Climatic analysis to spatial variation of (COVID-19) outbreak through the world}

In the early dates of the outbreak, countries with relatively lower temperature and lower humidity (such as Korea, Japan and Iran) see severe outbreaks than warmer and more humid countries (such as Singapore, Malaysia and Thailand) [1]. Generally, a specific type of climate zone will be found at similar latitudes in both northern and southern hemispheres. Except the continental climates, that are not found at higher latitudes in the southern hemisphere, in which the land masses are not wide enough to produce this climate pattern [3]. So, countries and areas with significant community transmission of (COVID-19) had distribution along the latitudes $(30-50)^{\circ}$ in northern hemisphere which is in winter season with average temperatures of $(5-11)^{\circ} \mathrm{C}$, low specific $(3-6 \mathrm{~g} / \mathrm{kg})$ and absolute humidity $(4-7 \mathrm{~g} / \mathrm{m} 3)$ [2,4] (Figure 3). 


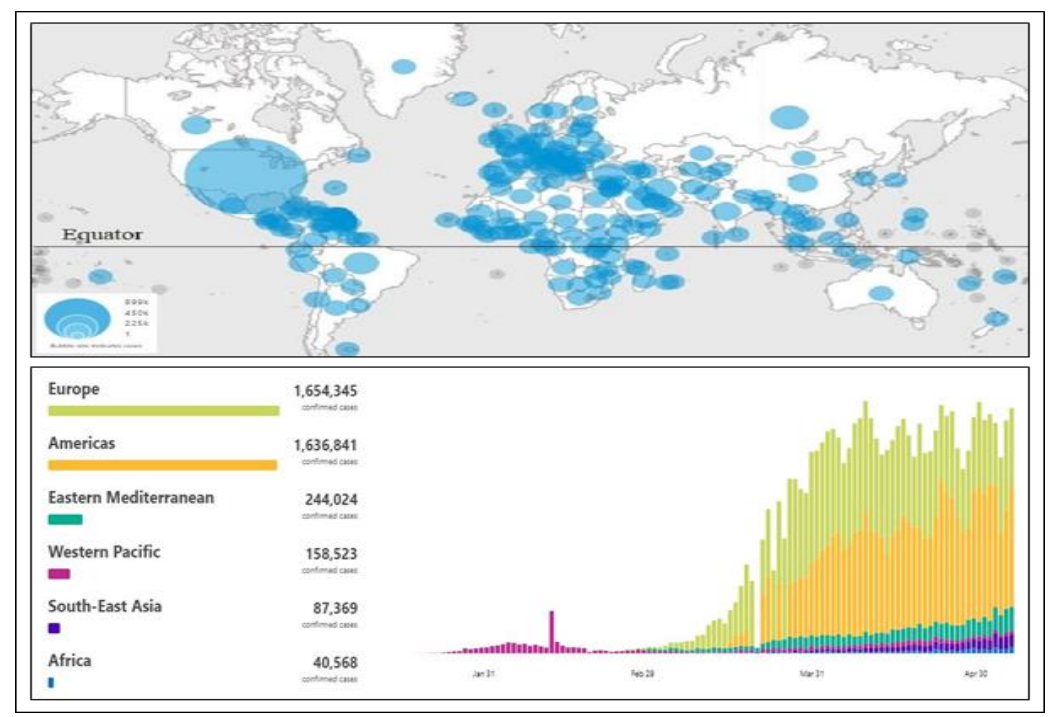

Figure 3: World (COVID-19) data according to (WHO) (09 $9^{\text {th }}$ May 2020)

A number of studies found that the mortality of patients could significantly reduce with the rise of temperature. Regarding the transmissibility of the disease, an in vitro study of transmissible mouse hepatitis virus and gastroenteritis virus discovered that at higher temperature, these kinds coronaviruses survived for a shorter time on the stainless steel surfaces [5]. A cross-sectional study found that the cumulative number of cases will decrease by $(0.86)$ for every $\left(1^{\circ} \mathrm{C}\right)$ increase in the minimum temperature [6]. Also, a modeling study suggested a transitory reduction in incidence in some areas may occur cautioning, The onset of spring and summer could, for example, give the impression that (COVID-19) were successfully contained, only for infections to increase again in (2020-2021) winter season. Some other studies come to the fact that the current spread prefers cool and dry conditions. Those studies also thought that the (2002-2003 SARS-CoV) linked to same conditions of climate. Based on that, in case the (COVID-19) pandemic follows (SARS CoV-2) trends; thus, worst case scenario of pandemic will be appeared. Results of two other studies reported that temperature correlate positively with the spread of infection rates; whereas, negatively correlate with humidity factor. Further studies investigated that temperature and humidity affect the transmission of (SARS-CoV-2), they claimed that increasing for every $\left(1^{\circ} \mathrm{C}\right)$ temperature and $(1 \%)$ in relative humidity led to decrease the infection rate by $(0.0383)$ and (0.0224), respectively [7]. Such recent studies reveal that the growth rate of (COVID-19) should gradually decrease with warmer weather in countries that located in northern hemisphere to increase in southern hemisphere with colder weather $[8,9,10,11]$. Another study predicted the decrease of (COVID-19) transmission by (43\%) on average for northern hemisphere countries with changing temperature between March to July 2020 and to increase by $(71 \%)$ for southern hemisphere [12]. A number of scientists claimed that the viral infections of this type unlikely to be spreaded rapidly in India, in contrast to other countries with colder climate. That is because the high temperature and high humidity decrease the activity of viruses to survive and remain potent. Although India is close to the epicenter and its dense population as well as poor hygiene in the urban centers; however, fewer number of confirmed cases of (COVID-19) has been reported [13]. The factors of temperature and humidity contribute a maximum of $(18 \%)$ of all the transmission factors $[14,15,7,10]$.

The virus's first emerged in China in middle of December and then has spread quickly. The global number of confirmed cases has rising most sharply in Europe and the US, and reached more than (100) thousands. Later, the (WHO) announced (COVID-19) to be a pandemic [16]. However, the virus reached the study area in late February with (391) confirm cases (5 deaths 
and 361 recovered) according to data of the Ministry of Health in Kurdistan Region which was published in $\left(09^{\text {th }}\right.$ May 2020) [17]. Now the number of infections around the world is (3822382) the confirmed cases including (263658) deaths reported to (WHO) as of $\left(09^{\text {th }}\right.$ May 2020), consist.

\section{RESULTS AND DISCUSSION}

\subsection{Climate characteristics of the study area}

Climate varies from region to another based on some general factors. The climate of the study area is influenced by a host of interacting factors, that are divided into two groups; (Stable and Dynamic factors), as stable factors such as geographical location (latitude and nearby water) and topography. The study area is located within subtropical zone in northern hemisphere which lies between two latitudes $\left(32^{\circ} 38^{\prime}-37^{\circ} 22^{\prime}\right)$ north. This location is based on the duration and the concentration of sunlight and the area that is affected by, with arrival of different pressure systems and air masses. Concerning to the nearby water, the area is regarded as one of the interior continental regions; however, five water bodies are adjacent to the study area such as (Mediterranean Sea, Black sea, Red sea, Caspian Sea and Arabian Gulf). Therefore, the study area is highly affected by the depressions of Mediterranean Sea and to a small extent the Arabian gulf, this, in turn, led to the domination of the continentally [18]. As the distance from the sea increases, the weather conditions become extreme. So, over the study area, there are often huge differences in the temperature between summer and winter, and also between day and night. In terms of topography, the study area can greatly affect the climate; the higher the place is above sea level the colder and wetter it will be. Mountain ranges often act as natural barriers that prevent wind and moisture that affecting the climate of the areas around it. The study area can be divided into two regions, mountainous and sub mountainous areas. The height above sea level increases with progress in south and southwest towards north and northeast, so that the elevation starts from less than $(200 \mathrm{~m})$ to more than (3600 $\mathrm{m})$ above sea level, which means that the area has a complex topography [19]. The temperature usually decreases by $\left(1^{\circ} \mathrm{C}\right)$ for every (100) meters with receive more rainfall in altitude; thus, this leads to a clear spatial variation of climate in the study area.

According to the dynamic factors such as (pressure systems, air masses and jet streams) which their quality and frequency vary according to seasons and from years, the study area is affected by some climatic depressions such as (Mediterranean low, Sudanese low, Convergence low, Indian low and Icelandic low), especially the first three climatic depressions that cause the occurrence of heavy rain and rainstorm in humid seasons (Figure 4). Anticyclones such as (Siberian high, European high, Azure high and Arabian high) causing changeable weather. For instance, anticyclones bring hot, sunny weather in summer; however, they cause cold weather including fog and frost during winter. Some air masses may control the climate condition during the period of their impacts such as Continental polar (cp), Maritime polar (mp), Continental tropical (ct), Maritime tropical (mt) and to a small extent Arctic air mass (A) [20]. Moreover, two different jet streams (Polar and Subtropical) can push depressions and air masses around and affect weather patterns of the study area. 


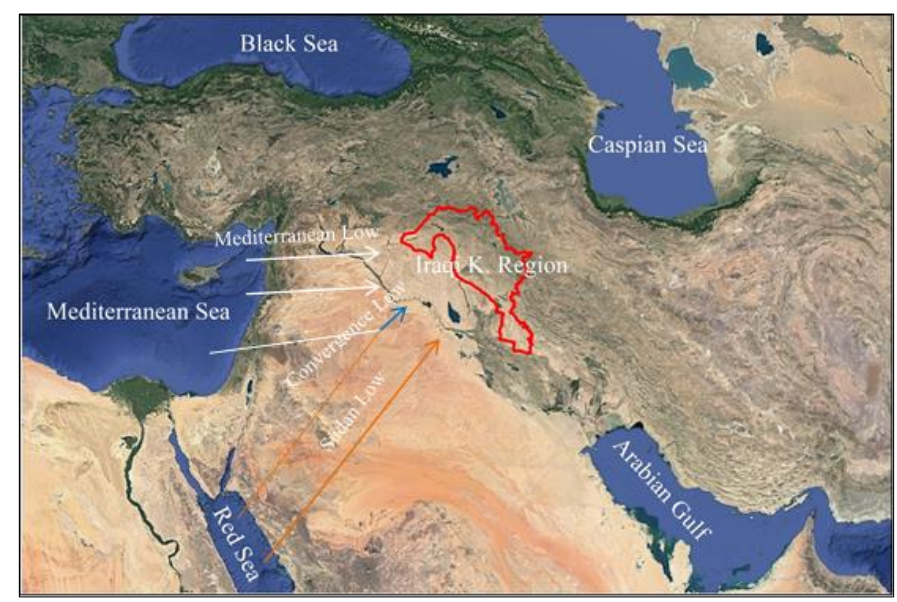

Figure 4: Depressions associated with rain in humid seasons in the study area depending on (www.accuweather.com)

Despite the small area of the region, which constitutes approximately (1/5) of Iraqi area, seasonal and spatial variations are clear in the values of climatic elements. This is due to the factors that were mentioned before which contributed to shaping the prevailing climate of the study area.

The most important characteristic of the climate of the study area is the emergence of the four seasons clearly. The details of data used in this study are shown in (Table 1) and (Figure $5 \&$ 6 ) which including the comparisons of the observed values over (10) stations for annual and seasonal rates. The data show high contrast in the values between the south and north regions in winter and summer seasons. These differences clearly distinguish the continental climate of Iraqi Kurdistan region. The minimum value of temperature for the study area was recorded in January, as in Khanaqeen station (the south of the Kurdistan Region) was $\left(9.50^{\circ} \mathrm{C}\right)$. On the other hand, Penjwen station which is located in the eastern of Kurdistan region (mountainous area) recorded $\left(-0.69^{\circ} \mathrm{C}\right)$ in the same month. However, the maximum value of temperature was recorded in July $\left(36.10^{\circ} \mathrm{C}\right)$ and $\left(28.42^{\circ} \mathrm{C}\right)$ for both stations respectively. The temperature decreases significantly from south and southwest toward north and northeast, so that there are a number of temperature isotherms values for the winter and summer seasons in different regions of the Kurdistan region (Figures 7). The seasonal and spatial variations of rainfall and humidity are much more compared to temperature factor, the average rainfall increases from south and southwest toward north and northeast. The amount of rainfall ranges between (>200-1000mm) in south and southwest, to north and northeast respectively; also, the humidity ranges between less than $(35 \%)$ in the south to more than $(50 \%)$ in the north as shown in (Figures 8). As for snowfall, its frequency in the mountainous areas is more than (12) times a year, especially in the far northeast of the region and rarely in the sub mountainous areas. Generally, there is a large spatial and seasonal variation of the values of rainfall and relative humidity, especially rain, which fluctuates greatly in annual rates due to topography on the one hand and annual variations of the arrival and frequency of depressions on the other hand, especially the Mediterranean depressions, which greatly affect the northern regions of the country. This is clear evidence that the temperature and humidity ratio are in huge gradient between winter and summer through north and south regions in Iraqi Kurdistan region. 
Table 1: The Values of Temperature $\left({ }^{\circ} \mathrm{C}\right)$ and Humidity $(\%)$ at the (10) Meteorological Station in Iraqi Kurdistan Region

\begin{tabular}{|c|c|c|c|c|c|c|c|c|c|c|c|c|c|}
\hline \multicolumn{14}{|c|}{ Temperature $\left({ }^{\circ} \mathbf{C}\right)$} \\
\hline Season & \multicolumn{3}{|c|}{ Winter } & \multicolumn{3}{|c|}{ Spring } & \multicolumn{3}{|c|}{ Summer } & \multicolumn{3}{|c|}{ Autumn } & \multirow{2}{*}{ Avg. } \\
\hline Station & Dec. & Jan. & Feb. & Mar. & Apr. & May & Jun. & Jul. & Aug. & Sep. & Oct. & Nov. & \\
\hline Zakho & 5.70 & 3.60 & 4.70 & 8.90 & 14.80 & 21.10 & 27.40 & 31.20 & 30.70 & 26.50 & 19.60 & 11.40 & \multirow{2}{*}{17.13} \\
\hline Seasonal Avg. & & 4.67 & & & 14.93 & & & 29.77 & & & 19.17 & & \\
\hline Duhok & 9.42 & 7.78 & 11.22 & 13.76 & 19.24 & 25.21 & 30.28 & 32.55 & 32.16 & 27.48 & 21.40 & 14.10 & \multirow{2}{*}{20.38} \\
\hline Seasonal Avg. & & 9.47 & & & 19.40 & & & 31.66 & & & 20.99 & & \\
\hline Shngal & 9.60 & 7.20 & 8.80 & 12.70 & 18.70 & 25.50 & 31.30 & 35 & 34.60 & 30 & 23.20 & 14.60 & \multirow{2}{*}{20.93} \\
\hline Seasonal Avg. & & 8.53 & & & 18.97 & & & 33.63 & & & 22.60 & & \\
\hline Erbil & 10.43 & 9.38 & 11.29 & 15.22 & 22.18 & 26.85 & 32.43 & 35.24 & 34.99 & 30.03 & 24.29 & 16.09 & \multirow{2}{*}{22.37} \\
\hline Seasonal Avg. & & 10.37 & & & 21.42 & & & 34.22 & & & 23.47 & & \\
\hline Soran & 6.68 & 4.63 & 6.86 & 11.49 & 16.31 & 21.80 & 28.23 & 31.70 & 31.76 & 27 & 20.35 & 12.12 & \multirow{2}{*}{18.24} \\
\hline Seasonal Avg. & & 6.06 & & & 16.53 & & & 30.56 & & & 19.82 & & \\
\hline Kirkuk & 10.80 & 9.10 & 10.90 & 15 & 20.80 & 27.60 & 33.30 & 36.10 & 35.30 & 31.40 & 24.90 & 16.40 & \multirow{2}{*}{22.63} \\
\hline Seasonal Avg. & & 10.27 & & & 21.13 & & & 34.90 & & & 24.23 & & \\
\hline Sulaimani & 8.76 & 6.89 & 8.78 & 12.78 & 17.76 & 23.86 & 30.11 & 33.62 & 33.27 & 28.81 & 22.29 & 13.94 & \multirow{2}{*}{20.07} \\
\hline Seasonal Avg. & & 8.14 & & & 18.13 & & & 32.33 & & & 21.68 & & \\
\hline Penjwen & 2.04 & -0.69 & 0.94 & 7.46 & 12.35 & 17.72 & 24.91 & 28.42 & 28.37 & 22.71 & 15.81 & 7.07 & \multirow{2}{*}{13.93} \\
\hline Seasonal Avg. & & 0.76 & & & 12.51 & & & 27.23 & & & 15.20 & & \\
\hline Darbandikhan & 10.48 & 8.46 & 9.57 & 13.69 & 18.53 & 24.56 & 30.87 & 34.97 & 34.60 & 30.25 & 23.69 & 15.53 & \multirow{2}{*}{21.26} \\
\hline Seasonal Avg. & & 9.50 & & & 18.93 & & & 33.48 & & & 23.16 & & \\
\hline Khanaqeen & 11.80 & 9.50 & 11.50 & 15.50 & 21.40 & 28.50 & 33 & 36.10 & 35.10 & 31 & 24.90 & 16.90 & \multirow{2}{*}{22.93} \\
\hline Seasonal Avg. & & 10.93 & & & 21.80 & & & 34.73 & & & 24.27 & & \\
\hline \multicolumn{14}{|c|}{ Relative Humidity (\%) } \\
\hline Season & & Winter & & & Spring & & & Summer & & & Autumn & & \multirow{2}{*}{ Avg. } \\
\hline Station & Dec. & Jan. & Feb. & Mar. & Apr. & May & Jun. & Jul. & Aug. & Sep. & Oct. & Nov. & \\
\hline Zakho & 71.90 & 72.50 & 70.50 & 62.80 & 55.60 & 44.70 & 30.50 & 27.90 & 26.50 & 31.80 & 45.20 & 60.50 & \multirow{2}{*}{50.03} \\
\hline Seasonal Avg. & & 71.63 & & & 54.37 & & & 28.30 & & & 45.83 & & \\
\hline Duhok & 73.88 & 71.56 & 69.56 & 63.69 & 56.50 & 45.61 & 31.25 & 28.08 & 27.98 & 32.53 & 45.99 & 62.15 & 5072 \\
\hline Seasonal Avg. & & 71.67 & & & 55.27 & & & 29.10 & & & 46.89 & & 50.13 \\
\hline Shngal & 64 & 69.10 & 61.30 & 54.10 & 46.20 & 33 & 23.10 & 21 & 21.50 & 25.40 & 36.20 & 49.10 & \\
\hline Seasonal Avg. & & 64.80 & & & 44.43 & & & 21.87 & & & 36.90 & & 42 \\
\hline Erbil & 72.54 & 71.66 & 66.95 & 63.26 & 54.91 & 42.20 & 32.29 & 28.91 & 30.15 & 34.01 & 47.71 & 62.96 & 5063 \\
\hline Seasonal Avg. & & 70.38 & & & 53.46 & & & 30.45 & & & 48.23 & & \\
\hline Soran & 73.42 & 76.09 & 74.06 & 68.56 & 67.88 & 62.43 & 52.46 & 50.12 & 50.41 & 51.92 & 63.71 & 70.30 & \\
\hline Seasonal Avg. & & 74.52 & & & 66.29 & & & 51 & & & 61.98 & & 63.45 \\
\hline Kirkuk & 69.31 & 71.08 & 65.47 & 57.51 & 49.71 & 33.52 & 23.11 & 21.68 & 23.04 & 25.91 & 37.24 & 56.75 & 4453 \\
\hline Seasonal Avg. & & 68.62 & & & 46.91 & & & 22.61 & & & 39.97 & & 7 \\
\hline Sulaimani & 71.84 & 71.45 & 66.06 & 62.19 & 55.64 & 42.00 & 27.63 & 24.76 & 23.65 & 30.36 & 46.71 & 63.35 & \\
\hline Seasonal Avg. & & 69.78 & & & 53.28 & & & 25.35 & & & 46.81 & & 48.80 \\
\hline Penjwen & 59.11 & 61.34 & 57.33 & 54.76 & 50.49 & 46.36 & 36.40 & 32.57 & 32.46 & 35.39 & 45.93 & 54.11 & \\
\hline Seasonal Avg. & & 59.26 & & & 50.53 & & & 33.81 & & & 45.14 & & 47.19 \\
\hline Darbandikhan & 65.10 & 70.60 & 65.30 & 62.40 & 54.70 & 43.50 & 26.20 & 23.80 & 22.30 & 29 & 36.10 & 48.50 & \\
\hline Seasonal Avg. & & 67 & & & 53.53 & & & 24.10 & & & 37.87 & & +5.02 \\
\hline Khanqeen & 64.27 & 68.53 & 63.91 & 59.07 & 50.82 & 35.14 & 26.65 & 24.38 & 23.18 & 28.34 & 36.22 & 54.46 & \\
\hline Seasonal Avg. & & 65.57 & & & 48.34 & & & 24.74 & & & 39.67 & & 44.58 \\
\hline
\end{tabular}




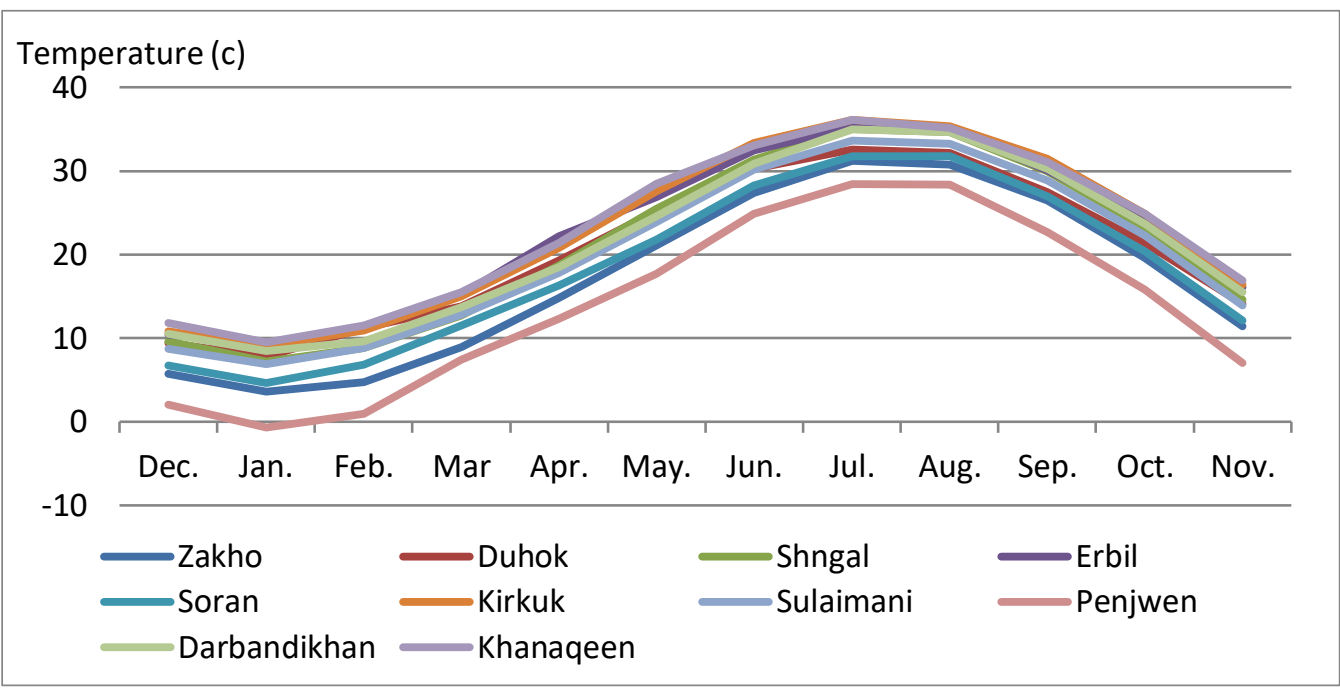

Figure 5: The Values of Temperature $\left({ }^{\circ} \mathrm{C}\right)$ at each of the (10) Meteorological Stations in Iraqi Kurdistan Region

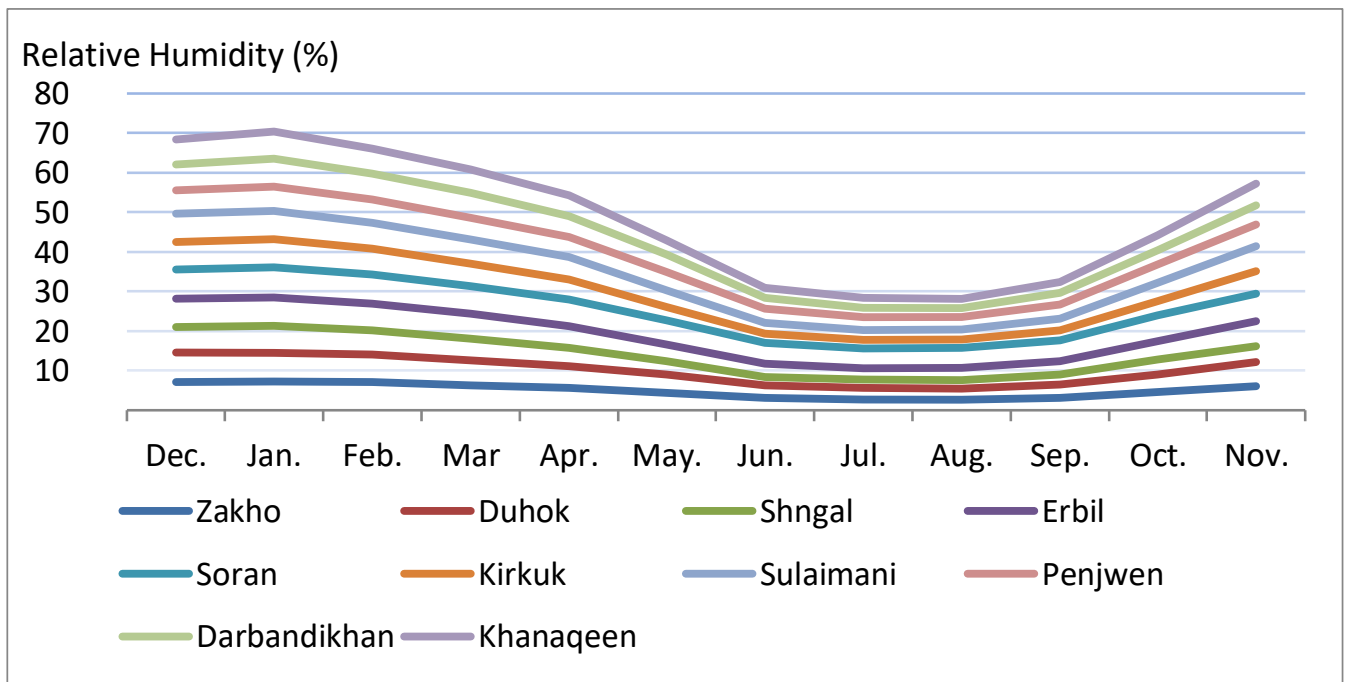

Figure 6: The Values of Humidity (\%) at each of the (10) Meteorological Stations in Iraqi Kurdistan Region 


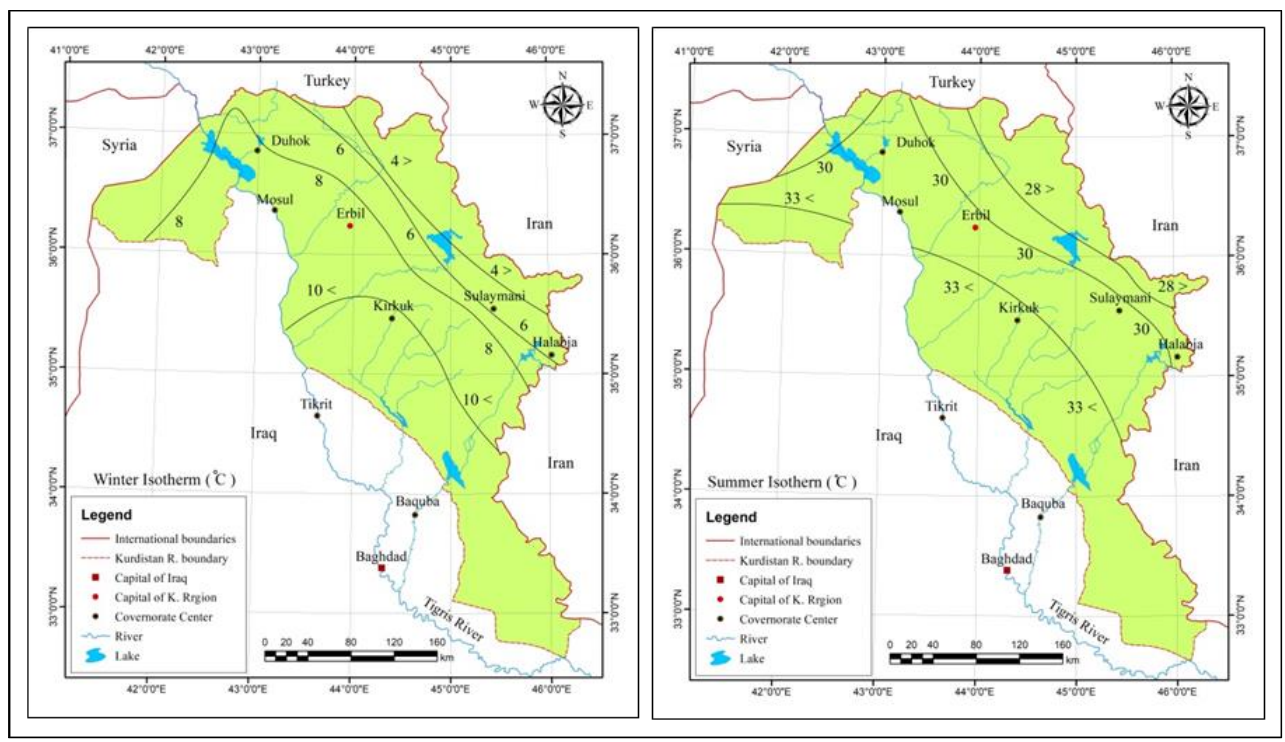

Figure 7: Thermal Isotherm $\left({ }^{\circ} \mathrm{C}\right)$ of Summer and Winter in Iraqi Kurdistan Region (Arc Map GIS 10.5)

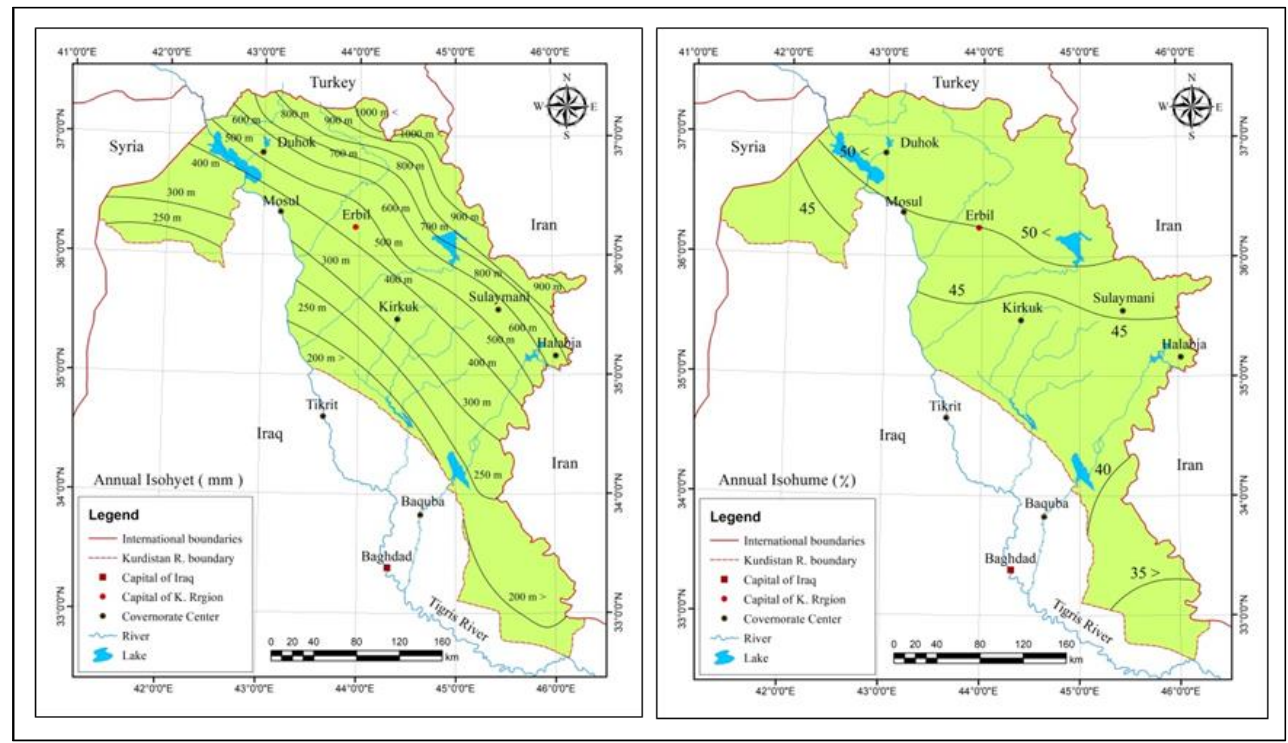

Figure 8: Annual Isoheyt (mm) and Isohume (\%) in Iraqi Kurdistan Region (Arc Map GIS 10.5)

Through the analysis of the climate control factors, elements and spatial variations that were mentioned above, a number of climatic regions can be distinguished in the study area, from north and northeast to south and southwest according to the Köppen (1936) [21*]. including the Mediterranean climate region ( $\mathrm{Csb}$ ) which is described as very cold winter and mild summer, Mediterranean climate region (Csa) cold winter and moderate to hot summer, SemiArid climate region (Steppe) (Bs) a little cold winter and hot and dry summer and Arid climate region (Desert) (Bw) mild winter and very hot and dry summer (Figure 9). 


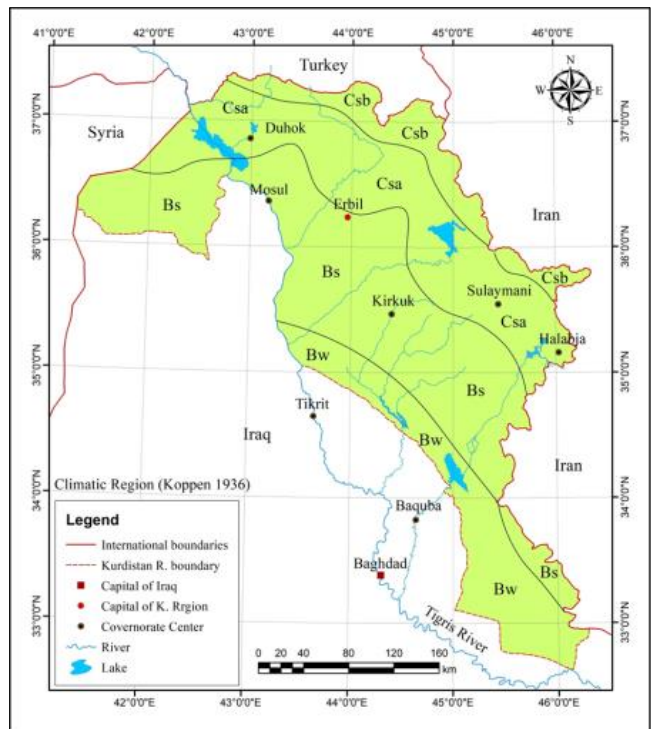

Figure 9: Climatic Regions of Iraqi Kurdistan Region depending on (Koppen 1936) (Arc Map GIS 10.5).

\subsection{Seasonal and spatial danger degree analysis to (COVID-19) in the study area}

Understanding the relationship between climate and (COVID-19) virus transmission is the key to predicting the intensity and the time of this epidemic. Studies showed that the rate of spread of the virus in Chinese cities with high temperatures and humid environments was slower compared to other areas of dry and cold nature. Scientists still out of right expectation, they claim that this virus will follow the other typical coronavirus cases, and can be expected a retreat in the summer. Whereas, this does not mean that the world will get rid of the crisis. The virus that causes (COVID-19) is new and there is no any firm data on how cases can be changed with the seasons. But there are some clues from other coronaviruses such as (SARS$\mathrm{CoV}$ ) and (MERS-CoV) that infect humans based on weather; so, (COVID-19) might eventually become seasonal.

The outbreak of the new disease around the world seems to have a preference for cool and dry conditions. The study area is located in northern hemisphere within similar latitudes of the first spread of (COVID-19), and has four seasons, the average temperature of winter is $\left(7.78^{\circ} \mathrm{C}\right)$ with severe differences among regions. For example, thermal range between Khanaqeen and Penjwen is approximately $\left(10.17^{\circ} \mathrm{C}\right)$ in winter and $\left(7.5^{\circ} \mathrm{C}\right)$ in summer.

On the other hand, the variation of relative humidity between Shngal and Soran stations is (\%29.13), despite the variation of other elements such as annual average of rainfall which is more than $(1000 \mathrm{~mm})$. The $(\mathrm{Bs})$ and $(\mathrm{Bw})$ climate regions have moderate winter, the average temperature in January is below $\left(11^{\circ} \mathrm{C}\right)$, but in $(\mathrm{Csb})$ region except winter months (December, January and February) the average temperature in March in the spring and November in the autumn is below $\left(11^{\circ} \mathrm{C}\right)$. However, in (Csa) region, the temperature in three months of winter is below this degree. In terms of humidity, it is clear from the provided data that the lower the temperature is the greater relative humidity will be and vice versa.

Generally, through this extensive climatological investigation, it has been determined that weather modeling could potentially explain the spread of the disease, making it possible to predict the areas that are most likely to be at higher risk of spread in the future. Therefore, it has been assumed that different temperature degree and humidity ratio in different regions of the study area might contribute to the balanced risk of infection with the virus.

Also, it should be taken into account that the virus spreads from person to others. The more population at any given place and the more they get into contact with each other, the more 
infections there will be. As well as, their behavior is key to understanding the propagation of the virus. Preventive measures such as placing travel restrictions, social separation, quarantine, and differences in government measures such as conducting early checks and the capacity hospitals may have a significant impact on the variance in the number of infected. So, noteworthy that the climate alone does not have a total impact on the spread of the disease as well as in the study area.

\section{CONCLUSION}

The study found that a great seasonal and spatial differences are in the climate of the study area that cause to emergence of four different climate regions such as Mediterranean climate region (Csb), Mediterranean climate region (Csa), semi-Arid climate region (Steppe) (Bs) and Arid climate region (Desert) $(\mathrm{Bw})$. Emerging data reveals to suggest that cold and dry conditions may facilitate the spread of the disease. According to the study area the lower the temperature is the greater relative humidity will be and vice versa. Therefore, we assume that seasonal differences of temperature and humidity in different regions of the study area might contribute to the balanced risk of infection with the virus. Also it is possible to have a mutation in the virus in future, which will change the factors affecting it as well as weather pattern.

As the temperature gets higher, subsequent studies are necessary to further validate our results and determine how (COVID-19) will behave in the upcoming months, and which areas and climate regions are most at risk. It seems that the rise of temperature and humidity alone would not completely control this epidemic. There is much more to learn about the transmissibility, severity, and other features associated with (COVID-19) and investigations have to going. Because preventive measures such as placing travel restrictions, individual health factors, social separation and quarantine may have had a significant impact on the variance in the number of injuries in countries of the world.

As any research, this study provides some limitations. As the climatic data collected were from different governmental available datasets, and data of some stations were not available to determine spatial variations. Also it was difficult to determine whether the new coronavirus will take specific course and behavior to spread only after passing enough time (mostly seasons) in order to appear the difference well. And Preventive measures like population mobility, social separation, cultural aspects and quarantine may have had an obvious reflection on the result of all climatic studies concern to (COVID-19).

\section{ACKNOWLEDGMENTS}

The Authors appreciate Abdulmuttalib Rafaat Sarhat for reviewing the article, thanks to Hassan Rostam Al-Bewani for obtaining some of references and special thanks to the presidency of Sulaimani polytechnic university and (KJAR) journal for their encouragement.

\section{References}

[1] J. Wang, K. Tang, K. Feng, and W. Lv, "High temperature and high humidity reduce the transmission of COVID-19." Available at SSRN 3551767 (2020).

[2] M. M. Sajadi, P. Habibzadeh, A. Vintzileos, S. Shokouhi, F. Miralles-Wilhelm and A. Amoroso, "Temperature, Humidity and Latitude Analysis to Predict Potential Spread and Seasonality for COVID19." Rochester, NY: Social Science Research Network; 2020.

[3] A. Balasubramanian, "WORLD CLIMATE ZONES \& GROUPS." Center for Advanced Studies in Earth Science, University of Mysore, 2013, https;//www.researchgate.net/publication/314211373

[4] G. Francesco Ficetola, and D. Rubolini, "Climate affects global patterns of COVID-19 early outbreak dynamics." medRxiv (2020).

[5] Y. Cai, T. Huang, X. Liu, and G. Xu. "The Effects of" Fangcang, Huoshenshan, and Leishenshan." Makeshift Hospitals and Temperature on the Mortality of COVID-19 (2020).

[6] M. Wang, , A. Jiang, L. Gong, L. Luo, W. Guo, C. Li, J. Zheng, Y. Chen, K. Zhing, H. Li, "Temperature 
significant change COVID-19 Transmission in 429 cities." MedRxiv (2020).

[7] J. Brassey, C.Heneghan, K.R.Mahtani, J. K.Aronson, "Do weather conditions influence the transmission of the coronavirus (SARS-CoV-2)," CEMB, www.cemb.net/oxford-covid-19, (2020)

[8] A. Notari, "Temperature dependence of COVID-19 transmission." arXiv preprint arXiv:2003.12417 (2020).

[9] R. Tosepu, , J. Gunawan, D. Savitri Effendy, L. Ali Imran Ahmad, H. Lestari, H. Bahar, and P. Asfian. "Correlation between weather and Covid-19 pandemic in Jakarta, Indonesia." Science of The Total Environment (2020): 138436

[10] B. Oliveiros, L. Caramelo, N. C. Ferreira, and F. Caramelo. "Role of temperature and humidity in the modulation of the doubling time of COVID-19 cases." medRxiv (2020).

[11] M. Ahmadi, A. Sharifi, S. Dorosti, S. Jafarzadeh Ghoushchi, and N. Ghanbari. "Investigation of effective climatology parameters on COVID-19 outbreak in Iran." Science of The Total Environment (2020): 138705.

[12] T. Carleton, and K. C. Meng. "Causal empirical estimates suggest COVID-19 transmission rates are highly seasonal." medRxiv (2020).

[13] D. Nevil Pinto, "Is India's Hot Weather Keeping Coronavirus at Bay? Experts Conflicted," TWC India, the weather channel, the times of India, March,03,2020. Available; https://weather.com/en$\underline{\text { IN/india/science/news }}$

[14] K. Chiyomaru and K. Takemoto. "Global COVID-19 transmission rate is influenced by precipitation seasonality and the speed of climate temperature warming." medRxiv (2020).

[15] J. Liu, J. Zhou, J. Yao, X. Zhang, L.Li, X. Xu, X. He et al. "Impact of meteorological factors on the COVID-19 transmission: A multi-city study in China." Science of the Total Environment (2020): 138513.

[16] J. Liebig, R. Jurdak, A. El Shoghri, and D. Paini. "The current state of COVID-19 in Australia: importation and spread." Available at SSRN 3559568 (2020).

[17] Kurdistan Regional Government, Ministry of Health, https://gov.krd/english/government/entities/moh/.

[18] D. C. P. Thalen, Ecology and utilization of desert shrub rangelands in Iraq. Springer Science \& Business Media, 2012

[19] M. Malcolm Walker, Climate of Iraq, A Full Year Study. AFCCC/CCD-05/002, 2005.

[20] J. E. Oliver, ed. Encyclopedia of world climatology. Springer Science \& Business Media, 2008.

[21] * (Koppen 1936) Climate Classification: $\mathrm{R} \leq 2 \mathrm{t} \quad \mathrm{R}$ : Rain fall $(\mathrm{mm}) \quad \mathrm{T}$ : Temperature $\left({ }^{\circ} \mathrm{C}\right)$

(M. Belda, , E. Holtanová, T. Halenka, and J. Kalvová. "Climate classification revisited: from Köppen to Trewartha." Climate research 59, no. 1 (2014): 1-13.) 